\title{
Growth analysis and shade experiment with Solanum nigrum L., the black nightshade, a leaf and fruit vegetable in West Java
}

\author{
F. T. J. M. Fortuin and S. W. P. Omta
}

Institute of Ecology, Pajajaran University, Bandung, Indonesia; Departement of Plant Physiology, State University of Groningen, Haren (Gr.), the Netherlands (correspondence address)

Accepted: 2 June 1980

Key words: Solanum nigrum L., black nightshade, shade, growth analysis, tropical vegetable

\section{Summary}

Solanum nigrum L., the black nightshade, is a populair vegetable throughout the tropics. Its use and cultivation were studied in West Java; here the young leaves and berries are eaten. A growth analysis experiment showed that the fruit production reached $1070 \mathrm{~g}$ per plant (30.5 tonnes per ha) 113 days after planting. This was about the same as that of high-yield tomato varieties, tested at the same station. When fruits and leaves were harvested the total yield was $580 \mathrm{~g}$ berries per plant ( 16.5 tonnes per ha) and $28 \mathrm{~g}$ leaves per plant ( 0.8 tonne per ha). Picking leaves influenced plant shape, relative growth rate and net assimilation rate, but had no effect on the distribution of biomass over roots, stems, leaves, flowers and fruits. Shade caused a decline in the total plant weight and changes in the distribution of biomass; the production of fruits was strongly affected, whereas the production of edible leaves was not affected by light shade and moderately by heavy shade. Shade had also a marked influence on the morphology of the leaves. In the berries no indication of toxicity could be demonstrated.

\section{Introduction}

Solanum nigrum $\mathrm{L}$., the black nightshade, a well-known weed in temperate regions, is a popular vegetable throughout the tropics. It has a low market price and a low economic value, but it is picked in the bush and along roadsides and cultivated in small fields and home gardens. It is sold on the markets of Hawaii, Guatemala, Trinidad, Suriname, western en southern Africa, India, Indonesia, the Philippines and China (Quisumbing, 1951; Watt \& Breyer-Brandwijk, 1962; Tindall, 1965; Terra, 1966; Herklots, 1972). It has a high nutritional value. In the leaves a high protein 
content is notable. This protein is rich in methionine, an amino acid scarce in other vegetables. For the berries the high iron, calcium and vitamine B contents should be mentioned (Omta \& Fortuin, 1979).

We studied the cultivation and use of S. nigrum in West Java. A survey in two villages revealed that two cultivars could be distinghuished, a large edible one and a small bitter one. Of the edible cultivar the young leaves and fruits were eaten. Both cultivars were used as a household medicine. The berries were regularly sold on the market.

Two experiments were conducted at the Vegetable Research Station Margahayu, Lembang, West Java, situated at an altitude of $1250 \mathrm{~m}$ on an andosol soil type. In a growth analysis two local practices of harvesting were evaluated. The productivity and growth characteristics of plants from which only fruits were harvested, were compared with those of plants from which both fruits and leaves were harvested. In a shade experiment the effect of light intensity on productivity was determined since the plants were often observed in situations of high plant density. In a forthcoming paper the effects of fertilization and spacing on productivity will be reported.

\section{Materials and growing conditions}

All plant material was taken from a single plant of the edible cultivar of $S$. nigrum in a village. It was hexaploid $(6 n=72)$, like the type species of the section Solanum: Solanum nigrum L.s.s. (Edmonds, 1978).

Seeds (thousand-seed weight $1.3 \mathrm{~g}, 90 \%$ germination) were sown in a seedbed on 15 August 1977. After two weeks the seedlings were transplanted into banana leaf pots, with a diameter of $4 \mathrm{~cm}$. The seedlings were planted in the field on 21 September 1977. Horse manure, mixed with rice straw, was applied at a rate of 15 tonnes/ha in the growth analysis experiment, and 22 tonnes/ha in the shade experiment. No artificial fertilizers were applied. Soil analysis by the Soil Research Institute of Bogor in 1973 revealed a texture of $27 \%$ sand, $69 \%$ clay and a nutrient content of $70 \mathrm{~g} \mathrm{C}, 7 \mathrm{~g} \mathrm{~N}, 2 \mathrm{~g} \mathrm{P}_{2} \mathrm{O}_{5}$ and $0.1 \mathrm{~g} \mathrm{~K}_{2} \mathrm{O}$ per $\mathrm{kg}$ dried soil. The preceding crop was maize.

Until the first fruit harvest the plots were sprayed twice a week with a mixture of the insecticide Supracide ( $5 \mathrm{~kg} / \mathrm{ha}$ ) and the fungicide Dithane $(5 \mathrm{~kg} / \mathrm{ha})$ for pest prevention. The crop was moderately attacked by diseases. In the shade experiment less then $1 \%$ of the plants was lost by bacterial wilt; in the growth analysis experiment nearly all plants were slightly attacked by rootknot nematodes. During the dry season, which lasted until the end of October, the plots were watered twice a week (total rainfall in September $29 \mathrm{~mm}$; October $9 \mathrm{~mm}$; November $240 \mathrm{~mm}$; December 307 $\mathrm{mm}$; January $236 \mathrm{~mm}$; Weather Station Margahayu Lembang). Weeding was performed once every two weeks until the foliage covered three quarters of the soil.

Fruits were harvested green, by cutting off whole fruit bunches. The small unedible fruit stems constituted about $10 \%$ of the total fruit weight. Leaf harvesting was performed by cutting off the last $5 \mathrm{~cm}$ of each branch consisting of small leaves and leaf and flower buds. 


\section{The growth analysis experiment}

\section{Methods}

The experiment was set up in 14 rows of 14 plants each; the spacing was $50 \times 70 \mathrm{~cm}$. Fruits were harvested from all plants, at 5 to 14 days intervals from 37 until 113 days after planting. Leaves were picked from four plants per row at 35, 48 and 57 days after planting. Plants from which only fruits were harvested were called 'non leaf harvested' (NLH); plants from which both fruits and leaves were harvested, were called 'leaf harvested' (LH).

Growth was followed from 13 to 120 days after planting. Regularly, at 9 to 14 days intervals, a whole row was uprooted except the edge plants. Of all plants length of the longest shoot part and total weight were measured. A sample was taken for detailed analysis. Roots, stems, leaves, flowers and fruits of these plants were weighed separately and the dry matter content was determined. The leaf area was calculated by means of a correlation between length and width and the surface of the leaves.

Afterwards leaf area ratio ( $\overline{\mathrm{L}} \overline{\mathrm{AR}})$ and the distribution of biomass over roots, stems, leaves and fruits were calculated. Between every two uprootings, the mean net assimilation rate ( $\overline{\mathrm{NAR}})$, the mean relative growth rate of the whole plant ( $\overline{\mathrm{RGR}})$ and of the leaf area ( $\overline{\mathrm{RGR}-\mathrm{LA}})$ were calculated. The daily fruit production during the harvest intervals and the average fruit production over the total field period were calculated. The protein content of the harvested leaves was determined by the Kjelldahl method. The stem length and plant weight of leaf harvested and non leaf harvested plants were compared by t-tests (Snedecor, 1967).

\section{General characteristics of growth of S. nigrum}

$S$. nigrum grew vigorously during the first three months after planting. Then senescence started and productivity dropped (Fig. 1). Stems and roots continued to grow until 106 days after planting. The mean dry matter content of the stems rose between 23 and 65 days from $6.0 \%$ to $16.2 \%$, probably by storage of carbohydrates. The dry matter content of the roots increased from $13.7 \%$ at 13 days to $17.8 \%$ at 23 days and stayed constant further on.

Leaf weight increased until 65 days (NLH plants), respectively 78 days (LH plants). Then the first leaves dropped. New leaves were formed, but they stayed very small: mean leaf size dropped from $13 \mathrm{~cm}^{2}$ at 78 days to $4 \mathrm{~cm}^{2}$ at 120 days (Table 1). The thickness of the leaves did not change. The dry matter content of the leaves varied between $9.9 \%$ and $14.6 \%$, with a mean of $11.2 \%$.

The first flowers opened 19 days after planting, 18 days later the first fruits were big enough to be harvested. The number of flowers increased until 65 days, then it decreased strongly. In the period of 92-106 days a sudden regrowth started. The first top in flower weight was followed by a top in fruit weight at 78 days, and a top fruit harvest at 87 days (Fig. 1). The second flower top did not result in high fruit yields anymore. 

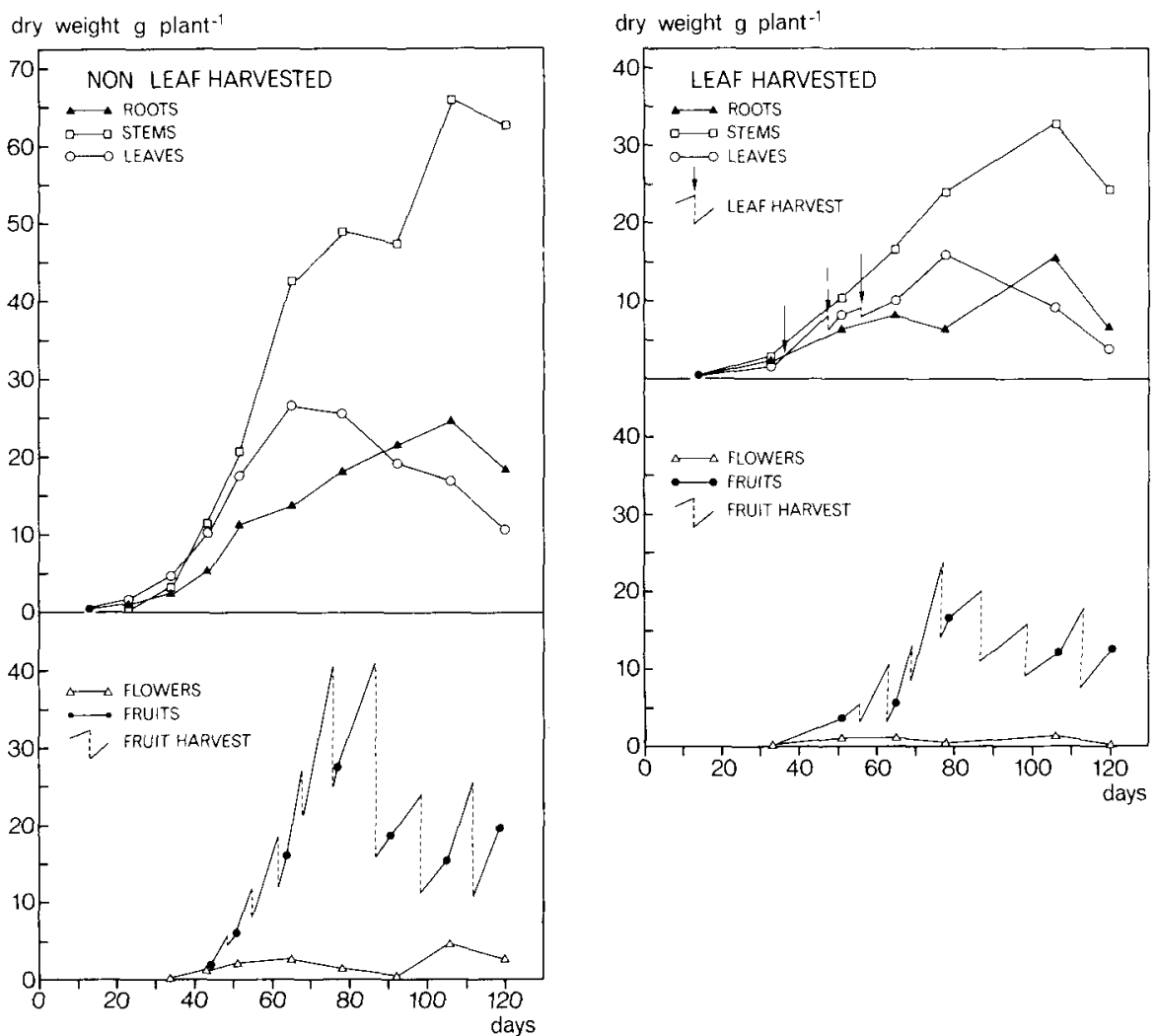

Fig. 1. a (left) dry weights of non leaf harvested plants of Solanum nigrum in the growth analysis experiment; $b$ (right) dry weights of leaf harvested plants. Fruits: this figure is constructed by combining the data obtained at the time of uprooting (black dots) with data of the amounts of harvested fruits and the growth rate of fruits between the harvest.

Table 1. Changes in mean leaf size and total leaf area per plant of leaf harvested (L.H) and non leaf harvested (NLH) plants in the growth analyis experiment.

\begin{tabular}{llllllllll} 
Days & & & & & & & & & \\
\hline 13 & 23 & 34 & 43 & 51 & 65 & 78 & 92 & 106 & 120
\end{tabular}

Leaf size $\left(\mathrm{cm}^{2}\right)$

NLH

LH

Leaf area $\left(\mathrm{m}^{2}\right)$

\begin{tabular}{lllllllllll} 
NLH & 10 & 10 & 12 & 14 & 13 & 14 & 13 & 9 & 5 & 4 \\
LH & 10 & - & 12 & - & 9 & 7 & 14 & - & 4 & 3 \\
& & & & & & & & & & \\
Leaf area $\left(\mathrm{m}^{2}\right)$ & & & & & & & & & & \\
NLH & 0.01 & 0.05 & 0.12 & 0.3 & 0.5 & 0.7 & 0.8 & 0.5 & 0.5 & 0.3 \\
LH & 0.01 & - & 0.10 & - & 0.2 & 0.2 & 0.4 & - & 0.2 & 0.1 \\
\hline
\end{tabular}



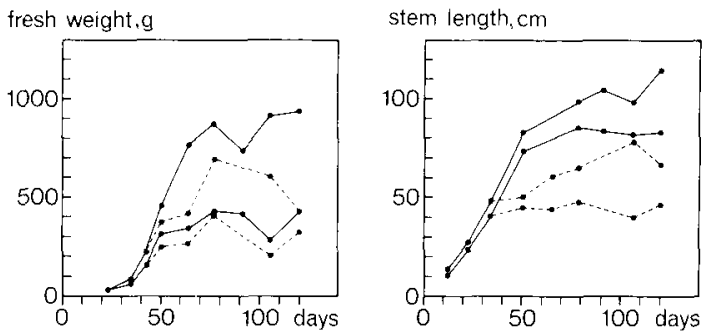

Fig. 2. a (left) fresh weights of above-ground parts in the growth analysis experiment; b (right) stem length in the growth analysis experiment.

\section{non leaf harvested plants, $1 \times$ standard deviation on both sides of the mean;} leaf harvested plants, same.

\section{The influence of harvesting leaves on the growth}

Plant shape was strongly affected by leaf harvesting: the LH plants had shorter main branches and more side branches than the NLH plants. The difference in stem length was significant for the period after the 53rd day (Fig. 2b). The mean shoot weight was always lower than that of NLH plants, but this difference was never significant (Fig. 2a).

Detailed analysis of the selected plants revealed the following. Storage of carbohydrates was lower in the stem of LH plants. The leaf weight of LH plants continued to increase 2 weeks longer than that of NLH plants (78 versus 65 days). In the period immediately after leaf harvests, RGR and RGR-LA of the LH plants was four times higher than that of NLH plants (Table 2) and NAR of the LH plants was nearly four times that of the NLH plants. The LAR of LH plants was 78 days after planting only slightly lower than that of the NLH plants, viz $40 \mathrm{vs.} 46 \mathrm{~cm}^{2} / \mathrm{g}$ plant.

Table 2. Mean relative growth rate of the whole plant $(\overline{\mathrm{RGR}})$, the leaves $(\overline{\mathrm{RGR}-\mathrm{LA}})$ and the mean net assimilation rate $(\overline{\mathrm{NAR}})$ of leaf harvested $(\mathrm{LH})$ and non leaf harvested $(\overline{\mathrm{NLH}})$ plants in the growth analysis experiment.

\begin{tabular}{|c|c|c|c|c|c|}
\hline \multicolumn{6}{|c|}{ Period (days) } \\
\hline & $13-33$ & $34-50$ & $51-64$ & $65-77$ & $78-106$ \\
\hline \multicolumn{6}{|c|}{$\overline{\operatorname{RGR}}(\mathrm{g} / \mathrm{g} /$ day $)$} \\
\hline NLH & 0.13 & 0.10 & 0.06 & 0.01 & 0.01 \\
\hline LH & 0.12 & & & 0.04 & 0.01 \\
\hline \multicolumn{6}{|c|}{$\overline{R G R-L A}\left(\mathrm{~cm}^{2} \mathrm{~cm}^{-2} \mathrm{day}^{-1}\right)$} \\
\hline NLH & 0.12 & 0.08 & 0.02 & 0.01 & \\
\hline LH & 0.12 & & & 0.04 & \\
\hline \multicolumn{6}{|c|}{$\overline{\mathrm{NAR}}\left(\mathrm{g} \mathrm{m}^{2}\right.$ day-1) } \\
\hline $\mathrm{NLH}$ & 11 & 11 & 9 & 3 & \\
\hline $\mathrm{LH}$ & 11 & & & 11 & \\
\hline
\end{tabular}




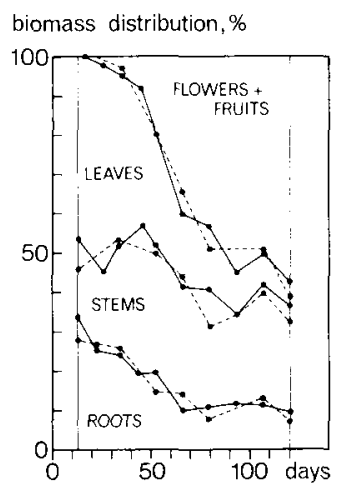

Fig. 3. Distribution of biomass during the growth. non leaf harvested plants; leaf harvested plants.

Leaf harvesting appeared to have no influence on the distribution of biomass (Fig. 3).

\section{Production of fruits and edible leaves}

The fruit yield of NLH plants was $1070 \mathrm{~g}$ per plant ( 30.5 tonnes/ha) after 113 days. The fruit yield of $\mathrm{LH}$ plants was significantly lower, $580 \mathrm{~g}$ per plant (16.5 tonnes/ha). The NLH plants developed a top production of $28 \mathrm{~g} /$ plant per day in the period of 78 to 87 days after planting; then the production dropped to a level of $10 \mathrm{~g} /$ plant per day (Fig. 5). At the end of the experiment (113 days) half of the plants still produced fruits and the average fruit production over the total field period (Fig. 4) was still rising. The production of the LH plants remained constant after 56 days at a level of $10 \mathrm{~g} /$ plant per day. Their average fruit production over the total field period was already declining at 113 days (Fig. 5). The average fruit production figures suggest that NLH plants could have stayed longer on the field, perhaps 4 or $41 / 2$ months, while for LH plants a period of 3 to $3 \frac{1}{2}$ months seems sufficient. In the green berries no traces of alkaloids could be demonstrated.

After two months the production of edible leaves was $28 \mathrm{~g}$ per plant $(0.8$ tonne/ha). The protein content of the leaves was $3.4 \%$ of the fresh weight.

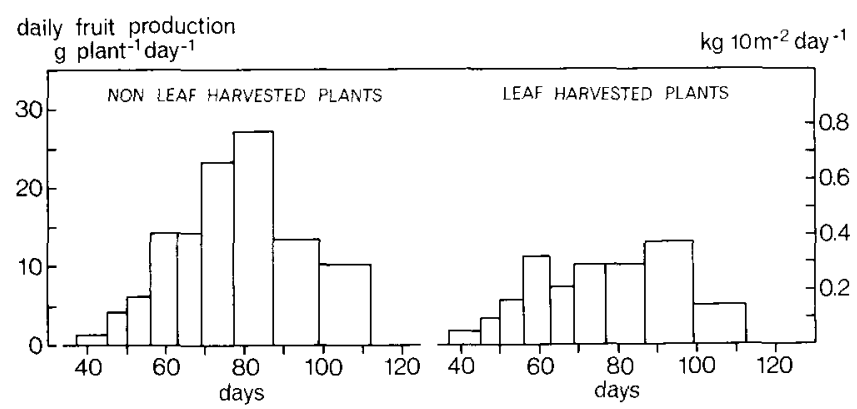

Fig. 4. Daily fruit production during the harvest intervals in the growth analysis experiment (fresh weights); $1 \mathrm{~kg} 10 \mathrm{~m}^{-2}$ corresponds with 1 tonne per ha. 


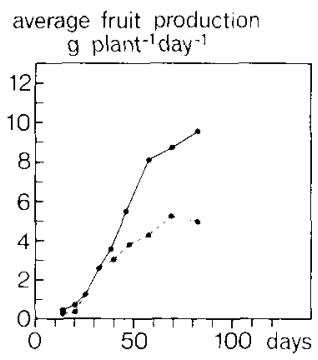

Fig. 5. Average fruit production over the total field period in the growth analysis experiment (fresh weights). non leaf harvested plants. leaf harvested plants.

\section{The shade experiment}

\section{Methods}

The experiment was set up in a randomized block design with four replications. Every plot contained 16 plants at a distance of $50 \mathrm{~cm} \times 50 \mathrm{~cm}$. The treatment consisted of five shade levels: $0 \%$ (full sunshine); $35 \%-45 \%, 50 \%-60 \%$ (light shading); $75 \%-85 \%$, and $95 \%$ (deep shading). Shading was performed by placing a bamboo frame over the plots, covered with alangalang (Imperata cylindrica L. Rausch) with plastic panels on the east and west side. Different shade levels were made by varying the quantity of alangalang and the number of black painted strips on the side panels. The shade levels were controlled and eventually corrected every two weeks. Fruits were harvested at the same days as in the growth experiment; leaves were harvested at 48 and 57 days after planting.

Shade caused changes in the microclimate. In deep shade the temperature of the air at noon was $2{ }^{\circ} \mathrm{C}$ lower than in full sunshine; the temperature of the soil at $5 \mathrm{~cm}$ depth was $11{ }^{\circ} \mathrm{C}$ lower, and at $10 \mathrm{~cm}$ depth $7^{\circ} \mathrm{C}$ lower than in full sunshine. It was observed that on very hot days deep shade plants wilted much sooner than the others. The humidity of the air increased from $28 \%$ in the sun to $52 \%$ in the deepest shade under calm weather conditions.

Experimental data were collected from the middle four plants of every plot. After 75 days one replication was uprooted, the others were cut. Shoots were weighed and stem length measured. From four plants, roots, stems, leaves, flowers and fruits were weighed separately, dry weight of leaves and fruits were determined and leaf area was calculated. For anatomical comparison transverse sections of leaves were studied. The rate of photosynthesis was determined volumetrically, by measurement of oxygen evolution, with leaves grown on 0,50 - 60 and $95 \%$ shade. Light conditions ranged from 1500 to 50.000 lux during this test.

For statistical analysis of the results, an analysis of variance for randomized block design, followed by an F-test, was used. The 'new Duncan multiple range test' was applied to see between which means a significant difference existed (methods from Snedecor, 1967).

\section{Influence on overall plant growth}

The total fresh weight decreased strongly under shade conditions. After 75 days plants of the $95 \%$ shade weighed less than one fifth of those of full sunshine. The 
Table 3. Mean fresh weight in grams of plants grown under different shade levels, 75 days after planting.

\begin{tabular}{|c|c|c|c|c|c|c|}
\hline \multirow[t]{2}{*}{ Parts of the plant } & \multicolumn{5}{|c|}{ Shade level $(\%)$} & \multirow[t]{2}{*}{ Analysis of variance } \\
\hline & 0 & $35-45$ & $50-60$ & $75-85$ & 95 & \\
\hline Roots & 50 & 30 & 40 & 20 & 10 & \\
\hline Stems & 232 & 180 & 225 & 113 & 73 & ** \\
\hline Present leaves & 130 & 93 & 113 & 56 & 46 & * \\
\hline Total amount of leaves & 172 & 132 & 153 & 74 & 57 & ** \\
\hline Flowers & 6 & 5 & 6 & 2 & 2 & $*$ \\
\hline Present fruits & 251 & 134 & 141 & 45 & 8 & ** \\
\hline Total amount of fruits & 490 & 270 & 280 & 110 & 40 & ** \\
\hline Whole plant & 570 & 440 & 530 & 230 & 140 & ** \\
\hline $\begin{array}{l}\text { Whole plant }+ \text { fruits }+ \\
\text { leaves harvested before }\end{array}$ & 950 & 620 & 710 & 320 & 180 & *** \\
\hline
\end{tabular}

* $\mathrm{P}<0.05 ;{ }^{* *} \mathrm{P}<0.01$

total fruit yield of $95 \%$ shade plants was less than one tenth of that of full sunshine plants. Stems, leaves and flowers of $95 \%$ shade plants weighed about one third of those of full sunshine plants; roots decreased to one fifth (Table 3). All plant parts of the $50-60 \%$ shade level were slightly, though never significantly, heavier than those of the $35-45 \%$ shade. No satisfactory explanation could be found.

Shade caused shifts in the distribution of the total weight. The relative weight of stems and leaves increased with increasing shade; in plants of $95 \%$ shade it was twice that of sun plants. The relative proportion of the fruits declined with increasing shading. In $95 \%$ shade the relative fruit weights were only one third of that in full sunshine (Fig. 6).

The influence on leaf properties and stem length

Shade had a marked influence on both morphological and physiological properties of the leaves. Leaves in the shade tended to become larger and thinner (Table 4). Cross sections through the leaf revealed that this was due to shortening of palisade

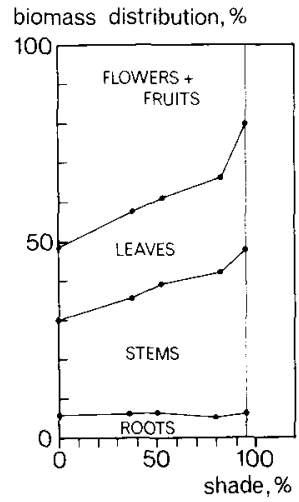

Fig. 6. The influence of shade on the distribution of biomass after 75 days of shade treatment. 
Table 4. Mean leaf area per plant, mean leaf area per gram plant, mean leaf surface and mean thickness of the leaves of plants grown under different shade levels.

\begin{tabular}{lccccccl}
\hline & \multicolumn{3}{l}{ Shade level $(\%)$} & & Analysis of variance \\
\cline { 2 - 6 } & 0 & $35-45$ & $50-60$ & $75-85$ & 95 & \\
Leaf area per plant $\left(\mathrm{m}^{2}\right)$ & 0.4 & 0.4 & 0.5 & 0.3 & 0.2 & $* *$ \\
Leaf area per g plant $\left(\mathrm{cm}^{2}\right)$ & 3.6 & 5.1 & 5.6 & 7.1 & 11.7 & $* *$ \\
Leaf surface $\left(\mathrm{cm}^{2}\right)$ & 14 & 12 & 16 & 16 & 21 & $*$ \\
Leaf mass per area $\left(\mathrm{mg} / \mathrm{cm}^{2}\right)$ & 30.3 & 24.2 & 23.8 & 21.6 & 19.8 & $* *$ \\
\hline
\end{tabular}

${ }^{*} \mathrm{P}<0.05 ;{ }^{* *} \mathrm{P}<0.01$.

parenchyma cells. The effect was so strong that the total leaf surface of plants of 50 - $60 \%$ shade was larger than that of sun plants, although the leaf weight was less and the whole plant was smaller. The leaf area per gram plant of $95 \%$ shade plants was more than 3 times that of sun plants, while their leaf weight per gram plant was only nearly twice that of sun plants (as can be calculated from Table 3 ). The rate of photosynthesis showed a normal curve for all types of leaves and no differences were found in the light compensation points (around 1700 lux). 24 days after planting the stems of plants of $95 \%$ shade were significantly longer than those of full sun and light shade ( $36 \mathrm{~cm}$ vs. $24 \mathrm{~cm}$ ). After 43 days the plants of $50-60 \%$ shade had become significantly longer $(79 \mathrm{~cm})$ than those in full sunshine and deep shade plants $(67 \mathrm{~cm}$ and $71 \mathrm{~cm}$ respectively).

\section{The production of edible leaves and fruits}

Fruit production decreased strongly with increasing shade. In light shade it was nearly half that in full sunshine and in deep shade only one fifth to one tenth. Shade also had a negative effect on the production of edible leaves, but much less than on fruit production. Up to $50 \%$ of shade no significant effect could be demonstrated. In all cases the harvested leaves formed about one quarter of the amount of leaves that was on the plant at the time of uprooting or cutting (Table 5).

Shade retarded fruiting: the first fruit harvest of sun plants took place after 37 days; that of deep shade plants after 45 days. Shade seemed to shorten the duration of fruit production, because in full sunlight the production per day was still rising after 75 days whereas in the deep shade fruit production per day was declining again (Fig. 7). The low production in the period of 63-69 days after planting remains unexplained, but was not caused by unfavourable weather conditions. Possibly fruit picking in the previous period was too rigorous.

Perhaps shade also influenced the quality of fruits and leaves. No detailed analysis of the nutritional value was made. The dry matter content of fruits and leaves was not significantly influenced by shading anyway. To test our impression that people liked shade leaves more than sun leaves, seven workers were asked to give their opinion on the five 'shading types' which were cultivated. In general they liked the leaves more as they were grown under deeper shade. Most people found the sun leaves too bitter. Perhaps the fact that leaves become thinner in the shade caused this higher appreciation. 
Table 5. The amount of edible leaves and fruits, produced until 75 days after planting by plants, grown under different shade levels (fresh weights in $\mathrm{kg} / 10 \mathrm{~m}^{2}$ ).

\begin{tabular}{lccccccc}
\hline & \multicolumn{3}{l}{ Shade level (\%) } & & \multirow{2}{*}{ Analysis of variance } \\
\cline { 2 - 6 } & 0 & $35-45$ & $50-60$ & $75-85$ & 95 & \\
Leaves & 1.7 & 1.5 & 1.6 & 0.7 & 0.4 & $* *$ \\
Fruits & 15.2 & 8.3 & 8.5 & 3.4 & 1.2 & $* *$ \\
\hline
\end{tabular}

** $\mathrm{P}<0.01$.

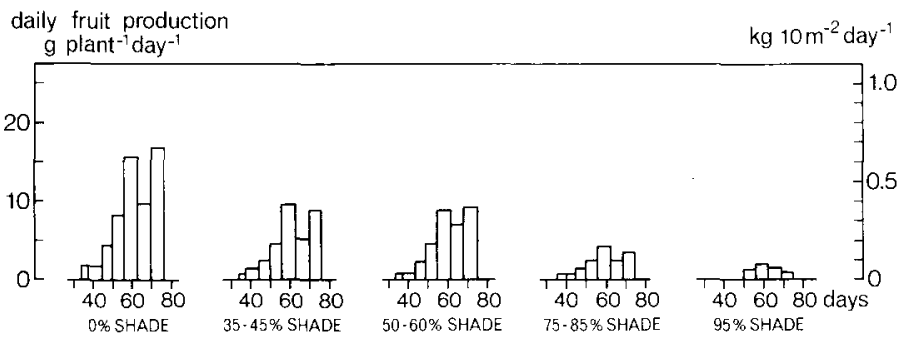

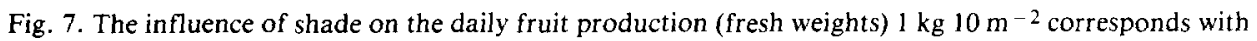
1 tonne per ha.

\section{Discussion and conclusions}

Concerning the physiological reactions on picking and shading the following remarks can be made.

- The increase in the ratio of photosynthetic active tissue (stems and leaves) to non-photosynthetic active tissue in the shade was in accordance with findings in other crops, such as barley and mangold (Kamel, 1959).

- The high NAR of LH plants in the period immediately after the leaf harvests is in accordance with observations on other plants, such as fruit trees (Tromp et al., 1976).

- The observation that on very hot days deep shade plants wilted much sooner than the other ones indicates that water uptake was limited by the low soil temperature of the $95 \%$ shade plots $\left(11^{\circ} \mathrm{C}\right.$ lower than that of the full sun plots). This is in accordance with findings of Abd el Rahman et al. (1959).

- The fact that no differences were found in the light compensation points of leaves of different shade treatments, is in contrast to the expectation that shade leaves have a lower light compensation point (Groen, 1973).

- The newly formed leaves and berries both constitute a sink for the photosynthetical production. In full sunshine the photosynthesis is high enough to guarantee the production of new leaves as well as that of new fruits. But the observation that shade affected production of fruits far more than production of leaves indicates that the sink of the new leaves is more effective than that of the fruits. 
Concerning the agricultural potential of Solanum nigrum the following remarks can be made.

- The production of berries of NLH pants was about the same as that of high yielding tomato varieties tested at the same station.

- In various publications the unripe berries are considered to be toxic on account of alkaloids (e.g. Heiser, 1962). Verbist (1971) demonstrated solasonine and solamargine in the leaves and green berries, but the quantity of these substances varied greatly. They disappeared during ripening of the fruit. In unripe berries, used in our experiments, no traces of alkaloids could be demonstrated.

- The yield of LH plants was low compared with that of NLH plants. Probably plant spacing was too wide for the small multibranched LH plants. The detailed analysis of the selected plants revealed that under conditions of full sunshine the ratio of fruits, leaves, stems, and roots was quickly restored to its original level before harvesting. It is expected that $\mathrm{LH}$ plants on a spacing of $40 \mathrm{~cm} \times 40 \mathrm{~cm}$ may produce the same fruit yields as NLH plants with an additional leaf yield of about 2 tonnes/ha.

- The protein content of the leaves, found in our experiments, was in accordance with data obtained from literature, viz $15-59 \mathrm{~g} / \mathrm{kg}$ edible portion (Terra, 1967; Oomen \& Grubben, 1977).

- From data obtained in the growth analysis experiment it can be calculated that when a spacing of $30 \mathrm{~cm} \times 30 \mathrm{~cm}$ is used and the whole plant is uprooted after one month, a leaf yield of at least 15 to 20 tonnes/ha may be expected. Therefore, Solanum nigrum is a valuable leaf vegetable. This way of cultivation is of special interest for use in the shade, because production of leaves is much less affected by shade than production of fruits and besides the shade leaves are better appreciated than sun leaves.

\section{Acknowledgements}

We are indebted to Professor $\mathrm{O}$. Soemarwoto for giving us the opportunity to do research at the institute of Ecology in Bandung, to Dr Soerachmat Koesoemo for the facilities at the Vegetable Research Station Margahayu, Lembang, and to Professor P. J. C. Kuiper of the Department of Plant Physiology, State University Groningen, for his supervision. We are grateful to Dr. R. Jellema, Department of Pharmacology, Groningen, for determining the alkaloid content and to Dr L. Pijnacker, Department of Genetics, Groningen, for carrying out the cytogenetical research.

Funds were received from the Groningen University Fund and the Henricus Munting Foundation. Plant material is available in the Herbarium Groninganae (GRO).

\section{References}

Abd el Rahman, A. A., P. J. C. Kuiper \& J. F. Bierhuizen, 1959, Preliminary observations on the effect of soil temperature on transpiration and growth of young tomato plants under controlled conditions. Meded. Landb. Hogesch. Wageningen 59(15):1-12.

Edmonds, J. M., 1978. Numerical taxonomic studies on Solanum L., section Solanum (Maurella). Bot. J. Linnean Soc. 76:27-51. 
Groen, J., 1973. Photosynthesis of Calendula officinalis L., and Impatiens parviflora DC., as influenced by light intensity during growth and age of leaves and plants. Meded. Landb. Hogesch. Wageningen 73-8.

Heiser, C. B., 1969. Nightshades, the paradoxical plants. Freeman \& Company, San Francisco.

Herklots, G. A. C., 1971. Vegetables in South-East Asia. Allen and Unwin, London.

Kamel, M. S., 1959. A physiological study of shading and density effects on the growth and the efficiency of solar energy conversion in some field crops. Meded. Landb. Hogesch. Wageningen 59-5.

Omta, S. W. F. \& F. T. J. M. Fortuin, 1979. Solanum nigrum L., the Black Nightshade, as a vegetable in the tropics, with special reference to West Java. Vegetables for the hot humid tropics 4:6-9. Puerto Rico.

Oomen, H. A. P. C. \& G. J. H. Grubben, 1977. Tropical leaf vegetables in human nutrition. Commun. Royal trop. Inst. No 69. Amsterdam.

Quisumbing, E., 1951. Medicinal plants of the Philippines. Department of Agriculture and Natural Resources, Manilla. Tech. Bull. 16.

Snedecor, G. D. \& W. G. Cochram, 1967. Statistical methods. lowa State University Press, Ames, lowa.

Terra, G. J. A., 1966. Tropical vegetables. Commun. Royal trop. Inst. No 54. Amsterdam.

Terra, G. J. A., 1967. Horticulture's contribution to human nutrition in the tropics. Proc. I8th int. hort. Congr. IV:83-97. University of Maryland.

Tindall, H. D., 1965. Fruits and vegetables in West Africa. FAO, Rome.

Tromp, J., H. Jonkers \& S. J. Wertheim (Ed.), 1976. Grondslagen van de fruitteelt; de fysiologie van de vruchtboom. Staatsuitgeverij, Den Haag.

Verbist, J. F., 1971. Contribution à l'étude des glucoalcaloides des Solanacées indigènes. Unité d'enseignement et de recherche des sciences pharmaceutiques de l'Université de Nantes.

Watt, J. M. \& M. G. Breyer-Brandwijk, 1962. The medicinal and poisonous plants of southern and eastern Africa. Livingstone, Edingburgh/London. 